\title{
PRICING AND OPERATIONAL EFFICIENCIES IN THE LIVESTOCK FEED MARKET IN ONDO STATE, NIGERIA ${ }^{1}$
}

\author{
Adegboyega E. Oguntade ${ }^{2}$ \\ Taiwo E. Mafimisebi ${ }^{2}$
}

\begin{abstract}
The Nigerian commercial poultry sector is dependent on commercial feeds. Evaluation of the operational and pricing efficiencies of poultry feed marketing is essential for improving efficiencies in the feed industry and lowering the price of poultry products. A multistage sampling technique was used to select the firms studied. Tools used to analyze data collected included index of pricing and operational efficiencies; and regression analysis. The firms studied handled about $\$ 251,870,000$ of feed per annum, had an annual Inventory Carrying Cost (ICC) of $\$ 4,587,762$ and an average ICC of $\$ 114,694$ per firm. The Marketing Costs (MC) for all the firms was $\$ 16,813,860$ per annum while the average MC was $\$ 420,347$. Major contributors to ICC were storage; handling and security costs while storage, transportation and capital costs were major contributors to MC. Efforts to minimize costs should therefore be focused at reducing transportation costs and optimal utilization of storage space. The Average Marketing Costs (AMC) declined with increase in quantity marketed (QM) while unit profit increased with QM. Firms therefore need to increase QM. Marketing Margin (MM) and MC were significantly different from each other. Also, QM was a significant explanatory variable of $\mathrm{MM}$, implying that there was no pricing efficiency in the market. Relative efficiency increased with QM, suggesting that firms should strive to increase the quantity of feed marketed. The major contribution of this study is that it provides information on the components of marketing costs and size economies in the poultry feed industry in Ondo State, Nigeria.
\end{abstract}

Keywords: Poultry feed, operational, pricing efficiency, marketing costs, Nigeria

Received April 4, 2010; Accepted August 18, 2010.

2 Department of Agricultural Economics \& Extension, The Federal University of Technology, Akure, Nigeria. Email: oguntadeade@yahoo.co.uk 


\section{Introduction}

The poultry industry is currently one of the most important sub-sectors of Nigerian agriculture. The value of the annual output of the commercial poultry sector was estimated at about $\mathrm{N} 170$ billion naira (ADENE and OGUNTADE, 2006). Feed is a major component of any livestock production enterprise as it accounts for an average of 60 to 70 percent of production (TAIWO, 1989; MAFIMISEBI, 2002; UNANG, 2003). The commercial poultry sector in Nigeria is feed dependent and requires about 1.87 million tonnes of feed per annum (ADENE and OGUNTADE, 2006). Current high prices of poultry feed coupled with occasional scarcity (MAFIMISEBI et al., 2002) calls for improvement in the efficiency of producing and marketing poultry feeds.

The evaluation of the operational and pricing efficiencies of poultry feed marketing industry is essential for improving the marketing activities of the industry. Pricing efficiency can be defined as the ability of a marketing system to efficiently allocate resources and coordinate the food production and marketing process in accordance with consumer directives (KOHLS and UHL, 1985). A marketing system is operating efficiently when the consumer price is equal to the producer price plus marketing costs. In an efficient marketing system therefore, marketing costs must exclude rents (HAU and OPPEN, 2004). Operational efficiency assumes that the quantum and quality of commodities and services are constant while efforts are directed at reducing their costs. The operational efficiency of a marketing system is enhanced when marketing costs are reduced at the same level of output (MAUYO et al,. 2007).

The effect of improved operational and pricing efficiencies in poultry feed marketing industry may be transmitted to poultry farmers in the form of reduced cost of procuring poultry feeds. This may eventually be translated to lower consumer price for poultry products. The strong demand for eggs and broiler meat and the increasing establishments of poultry farms (MITCHEL et al., 1999; ADENE and OGUNTADE, 2006) 
seem to suggest that the effect of reduced cost of poultry feeds, if so transmitted, will be very significant. Increased efficiency benefits farmers, traders, processors, wholesalers, retailers, consumers and society as a whole (CRAWFORD, 1997; HAU and OPPEN, 2004). This paper therefore aims at assessing the pricing and operational efficiencies of the firms marketing poultry feed in Ondo State, Nigeria.

\section{Methodology}

\subsection{Theoretical framework}

This theoretical framework addresses the key economic concepts underlying the analytical tools applied in this study. These are economies of size and; pricing and operational efficiencies.

Economies of size result from spreading fixed costs over a large number of units of products marketed. Because fixed costs remain the same irrespective of the number of units marketed, as the number of units marketed increases, the fixed cost per unit falls. This also causes the total cost per unit to fall. This relationship holds in the short run and over a range of output. How fast the total cost per unit falls depends on how large fixed costs are relative to the total costs and on whether average variable and marginal costs fall over a wide range of output (WATSON and HOLMAN, 1977). Methods commonly cited in the analyses of economies of size include descriptive analysis, economic engineering, average function analysis and frontier function analysis (KER and HOWARD, 1993). The average functional approach has been used widely to model economies of size and scale in agricultural production (STEFANOU and MADDEN, 1988). In such studies, the relationship between farm size and per hectare production costs is displayed by scatter plots. The "envelope" curve of the scatter plots is considered as the long-run average cost curve, which conceptually, represents the most efficient method of producing each level of output, given all possible 
combinations of variable and fixed inputs (HERRUZO and MOROTE, 1996). A declining average cost (curve) is an indication of economies of size in an industry (WATSON and HOLMAN, 1977). Given the relationship between profit, revenue and costs, it is expected that as the total cost per unit falls with increases in the number of units marketed, profit per unit will increase. This is a motivation for marketers to strive to expand their outputs.

Two types of marketing efficiencies could be distinguished. These are operational and pricing efficiencies. Operational efficiency refers to the extent to which costs can be reduced while output levels are either maintained or even increased (CRAWFORD, 1997; KÄHKÖNEN and LEATHERS, 1999). Marketing costs are incurred when commodities move from the point of production to the final market, whether they are moved by farmers or marketing intermediaries. As the product is moved over greater distances, through more intermediaries and given better packaging, marketing cost increases. Marketing costs include labour, transport, packaging, containers, rent, utilities, advertising, selling expenses, depreciation allowances and interest charges (CRAWFORD, 1997). In a perfectly competitive market, the marketers will strive to minimize marketing costs in an attempt to maximize their profits. As they minimize costs, parts of the gains of cost minimization are passed on to the consumers in terms of reduced prices. Cost analysis is therefore central to the notion of operational efficiency (WARRACK, 1972). The lower the cost, the higher is the operational efficiency. Firms with lower marketing costs are hence deemed to be more efficient. This has led to the concept of relative efficiency in which the unit cost of each firm in the sector is compared with the unit cost of the most efficient firm (the least cost firm) (FOLAYAN et al,. 2007; MAUYO et al,. 2007).

Pricing efficiency focuses on the need for prices in a commodity's market to correspond to values being exchanged. Crawford (1997) states that prices of a given product will be related over space and time, and between forms if markets are operating efficiently. A market is therefore deemed efficient when there is absence of arbitrage opportunities, i.e. it is not 
possible to earn a profit simply by buying the commodity in one market and selling the commodity in a second market. The difference in the price of commodity between two markets must be accounted for by transportation cost and other handling charges (KÄHKÖNEN and LEATHERS, 1999; OLADAPO et al., 2007).

Where pricing efficiency exists, marketing margin should reflect values being delivered. Marketing margin is the difference in prices at two different points in a marketing chain. A commonly reported marketing margin is the farm-to-retail spread, which measures the difference between the retail price and the farm level price for a commodity (KÄHKÖNEN and LEATHERS, 1999). The margin must cover the costs of moving the product from one stage to the next and provide a reasonable return to the marketers (CRAWFORD, 1997).

In line with Shepherd-Futrel model, marketing efficiency is sometimes calculated as net margin divided by marketing cost and the result multiplied by one hundred (OLUKOSI and ISITOR, 1990; BABATUNDE and OYATOYE, 2005; UGWUMBA, 2009). In the alternative, the coefficient of marketing efficiency can be expressed as the difference between total sales revenue and total cost divided by total cost incurred (ARENE, 1998). If marketing efficiency is to be exactly $100 \%$, net margin must be equal to marketing costs. For a given market, the equality of the net margin and marketing costs could be tested via paired sample t-test. This could serve as an indicator of pricing efficiency in the market.

\subsection{Anal4ytical Technique}

To evaluate empirically the pricing and operational efficiencies of the feed marketing firms, the tools used included cost and returns analysis; and indices of pricing and operational efficiencies. Regression analysis was used to assess how marketing margin varies with marketing costs, how total marketing cost varies with the quantity of feed marketed per year and how marketing margin varies with the quantity of feed marketed per year 
a) Cost and Returns Analysis

This was used to determine the profit margin of the feed marketing firms and is specified as follows:

$\Pi=\mathrm{TR}-\mathrm{TC}=\mathrm{P} \times \mathrm{Q}-\mathrm{TMC}$,

where $\Pi=$ Profit $; \mathrm{TR}=$ Total Revenue ; and $\mathrm{TMC}=$ Total Marketing Cost.

Profit in terms of output is given by TR from feed sales less the TMC. TMC is an aggregation of the costs of storage space, damages, handling, security, transportation and capital.

b) Economies of size

Economies of size in the industry were appraised by relating the TMC and the average marketing costs (AMC) to the quantity of feed marketed (Q). TMC was estimated as a third degree function of the quantity of feed marketed as in equation (1).

$\mathrm{TMC}=\mathrm{a}+\beta_{1} \mathrm{Q}+\beta_{2} \mathrm{Q}^{2}+\beta_{3} \mathrm{Q}^{3}+\varepsilon$,

where $\beta_{1} \beta_{2}$ and $\beta_{3}$ are coefficients and $\varepsilon$ is the error term.

The explanatory variables were allowed to enter the regression in a stepwise manner. A lead equation was chosen among the models generated based on the values of the adjusted $\mathrm{R}^{2}$ and the mean square residual.

The AMC function was thereafter derived from the TMC function as $\mathrm{TMC} / \mathrm{Q}$. 
c) Relationship between Marketing Margin (MM) and Marketing Costs (MC)

The equation of MM was estimated as a third degree function of $\mathrm{MC}$ as in equation (2).

$\mathrm{MM}=\mathrm{a}+\beta_{1} \mathrm{MC}+\beta_{2} \mathrm{MC}^{2}+\beta_{3} \mathrm{MC}^{3}+\varepsilon$,

where $\beta_{1}, \beta_{2}$ and $\beta_{3}$ are coefficients and $\varepsilon$ is the error term.

The explanatory variables were also allowed to enter the regression in a stepwise manner. A lead equation was again chosen among the models generated based on the values of the adjusted $\mathrm{R}^{2}$ and the mean square residual.

d) Relationship between Marketing Margin and Quantity Marketed

A direct estimation of the marketing margin as a third degree function of the quantity marketed $(\mathrm{Q})$ was carried out as in equation (3).

$\mathrm{MM}=\mathrm{a}+\beta_{1} \mathrm{Q}+\beta_{2} \mathrm{Q}^{2}+\beta_{3} \mathrm{Q}^{3}+\varepsilon$,

where $\beta_{1,} \beta_{2}$ and $\beta_{3}$ are coefficients and $\varepsilon$ is the error term.

The explanatory variables were allowed to enter the regression in a stepwise manner. A lead equation was chosen among the models generated based on the values of the adjusted $\mathrm{R}^{2}$ and the mean square residual

e) Index of Pricing Efficiency

The t-test was used to compare the mean marketing margin with the mean marketing costs. Mathematically, the $\mathrm{t}-$ statistic was computed as: 


$$
t=\frac{\bar{D}}{\frac{\sqrt{\sum D^{2}-\left(\sum D\right)^{2} / N}}{N(N-1)}}
$$

where $\mathrm{D}=$ difference between the marketing margin and marketing costs of paired observations; $\mathrm{D}=$ means of the difference; $\mathrm{N}=$ Number of paired observations; and N-1 = Degrees of freedom.

The hypothesis tested was:

Ho: marketing margin is equal to marketing costs.

Ha: marketing margin is not equal to marketing costs

f) Measure of Market Performance by Efficiency

Operational efficiency was appraised based on profitability and marketing costs of the firms. Assessment of profitability is a comparison of unit profit across the firms and how the unit profit varies with the level of output. Operational efficiency based on marketing costs is a comparison of the least marketing cost incurred by a firm (most efficient firm) in the industry to the marketing cost incurred by each of the firms whose performance is being rated in the industry. The lesser the marketing cost of a firm, the more efficient is the operation when compared with other firms in the marketing industry (FOLAYAN et al., 2007; Mauyo et. al. 2007). The following equation was applied.

Efficiency $=\left(\mathrm{MC}_{\mathrm{L}} / \mathrm{MC}_{\mathrm{i}}\right) \times 100$,

where $\mathrm{MC}_{\mathrm{L}}=$ unit marketing cost of the firm with the least unit cost (most efficient firm); and $\mathrm{MC}_{\mathrm{i}}=$ unit marketing cost of the $\mathrm{i}^{\text {th }}$ firm in the industry. 


\subsection{The Study Area}

The study was carried out in Ondo State, Nigeria. The state is situated in southwestern part of Nigeria. It lies between longitude $4^{\circ} 30^{\prime}$ East and $6^{\circ}$ $00^{\prime}$ East of Greenwich Meridian and latitude $5^{\circ} 45^{\prime}$ and $8^{\circ} 15^{\prime}$ North of the Equator. Ondo State is made up of 18 local government areas (LGAs) and lies entirely in the tropics; with high temperature all the year round, heavy rainfall during the rainy season lasting from April to October and dry season from November to March. About $80 \%$ of the inhabitants are farmers. They grow both cash and food crops. The cash crops grown include oil palm and cocoa. They also grow food crops such as yams, maize, cassava, cocoyams etc. Crop production is mostly at small-scale level. Poultry is a major agricultural enterprise. About 20,737 households keep poultry in the state (ADENE and OGUNTADE, 2005).

\subsection{Sampling Technique and Data collection}

A multistage sampling technique was used to select the feed marketing firms studied. The first stage was a purposive sampling of 2 LGAs which have the highest concentration of registered poultry farms in the state. The expectation is that the demand for poultry feed will be highest in these LGAs. From each LGA, 20 poultry feed marketers were randomly selected making a total of 40 marketers. Appointments were set up with each selected marketer for specific days. Visits were made to each marketer on the agreed days to conduct personal interview using a pretested interview guide. Aside from the interviews, information was extracted from the records kept by the marketers. Information collected include hours of business, initial capital, turnover, number of orders made per annum, market prices, various components of inventory and marketing costs, mode and cost of transport, opinions regarding the requirements of buyers, determinants of prices and problems faced in trade, among others. 


\section{Results and Discussion}

\subsection{Inventory carrying cost (ICC)}

The various components of ICC are costs storage space, damages, handling, security and capital. Table 1 presents the structure of the ICC. The table shows that storage space cost accounted for $56.34 \%$ of ICC. It was followed by security with $19.45 \%$ and handling charges with $19.17 \%$. Security cost is the cost of providing guards for the store cum distribution outlet during the night.

Table 1 - Components of inventory carrying costs

\begin{tabular}{|l|c|c|c|c|}
\hline \multirow{2}{*}{ Cost Item } & \multicolumn{3}{|c|}{ Cost (Naira) } & \multirow{2}{*}{ Percent of Total Inventory Carrying Cost } \\
\cline { 2 - 4 } & Total & Average & Per Bag & \\
Storage Space Cost & $2,584,650$ & 64,616 & 15.39 & 56.34 \\
\hline Damages & 5,820 & 146 & 0.03 & 0.13 \\
\hline & & & & \\
Handling Charges & 879,600 & 21,990 & 5.24 & 19.17 \\
\hline Security & 892,500 & 22,313 & 5.32 & 19.45 \\
\hline & & & & \\
Cost of Capital & 225,192 & 5,630 & 1.34 & 4.91 \\
\hline $\begin{array}{l}\text { Total Inventory } \\
\text { Carrying Costs }\end{array}$ & $4,587,762$ & 114,694 & 27.32 & 100.00 \\
\hline
\end{tabular}

Source: Authors' computation.

The total amount spent on inventory in the industry in 2008 was $\AA 4,587,762$ while the ICC per feed marketer was $\$ 114,694$. The absolute ICC expressed as a percentage of the average inventory value was a maximum of $154.5 \%$ and minimum of $6.52 \%$. The mean was $64.92 \%$ and the median was $53.68 \%$. 
With the ICC expressed as a percentage of the total cost of feed marketed per annum, the maximum was $6.44 \%$ and the minimum was $0.54 \%$. The mean was $3.30 \%$ while the median was $2.99 \%$.

\subsection{Marketing Costs}

The components of the Marketing Costs are the costs of storage space, damages, handling, security, transportation and capital. Table 2 presents the MC with its structure. The table shows that transportation accounted for $39.95 \%$ of $\mathrm{MC}$ while storage space cost accounted for $20.50 \%$. The cost of capital accounted for $19.11 \%$ while damages, handling and security accounted for $7.74 \%, 6.54 \%$ and $5.31 \%$, respectively.

Table 2 - Cost components of marketing costs

\begin{tabular}{|l|c|c|c|c|}
\hline \multirow{2}{*}{ Cost Item } & \multicolumn{3}{|c|}{ Cost (Naira) } & Percent of Total Marketing Cost \\
\hline \multirow{2}{*}{ Storage Space Cost } & $3,446,200$ & 86,155 & 20.52 & Total \\
\cline { 2 - 6 } & Total & Average & Per Bag & 20.50 \\
\hline Damages & $1,302,000$ & 32,550 & 7.75 & 7.74 \\
\hline Handling Charges & $1,098,967$ & 27,474 & 6.54 & \\
\hline Security & 892,500 & 22,313 & 5.32 & 6.54 \\
\hline & & & & 5.31 \\
\hline Transportation & $6,716,533$ & 167,913 & 40.00 & \\
\hline Cost of Capital & & & & 39.95 \\
\hline Total Marketing Costs & $16,813,860$ & 420,347 & 100.13 & \\
\hline
\end{tabular}

Source: Authors' computation. 
The total amount spent on marketing by all the firms in 2008 was

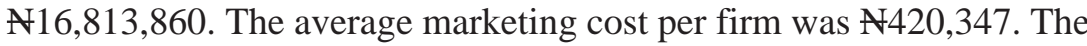
marketing cost estimated as a percentage of the initial cost of feed marketed by respective firms ranged from $5.08 \%$ to $20.37 \%$. The mean was $8.55 \%$ while the median was $7.86 \%$.

\subsection{Volume of trade and economies of size}

The total quantity of feed marketed by the poultry feed distributing firms in 2008 was 167,913 bags ( 1 bag weighs $25 \mathrm{~kg}$ ). The firm with the highest turnover marketed 20,667 bags per annum while the firm with the smallest turnover marketed 1,133 bags per annum. The median total quantity marketed was 2,660 bags while the mean was 4,198 bags. The total initial cost of the 167,917 bags marketed by all the firms was $251,870,000$. About $62.5 \%$ of the firms had a turnover of less than 5000 bags per annum, while $35.0 \%$ had a turnover of between 5000 and 10,000 bags. One firm or $2.5 \%$ had a turnover of over 20,000 bags per annum.

The estimated TMC function is in equation (6) from which the AMC function in equation (7) was derived.

$\mathrm{TMC}=112,434+0.07336 \mathrm{Q}$

$F=1420.05$

$\underline{\mathrm{R}^{2}}=0.974$

$\mathrm{R}^{2}=0.973$

MS Residual $=2154.184$ 
Equation (6) indicates a total fixed cost of $\$ 112,434$ per firm in the

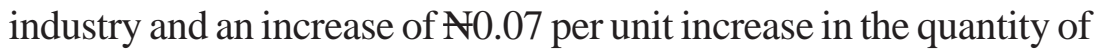
feed marketed.

$\mathrm{AMC}=\mathrm{TMC} / \mathrm{Q}=(0.07336+112,434) / \mathrm{Q}$

The plot of equation (7) is presented in Figure 1. The figure indicates that economies of size continue to be enjoyed as the quantity of feed marketed increases. It appears such cost reductions become negligible after the 16,000 bags. It could therefore be tentatively suggested that firms in the industry should strive to market not less than 16,000 bags of feed per annum. Only one firm out of 40 handled up to this quantity per annum. The difference between this quantity and the mean and median quantities are 11,802 bags and 13,340 bags; respectively. The cost that could be saved by increasing the quantity marketed from the mean and median levels to the 16,000 bags suggested are $\AA 29,500$ and $\AA 18,692$ per annum; respectively.

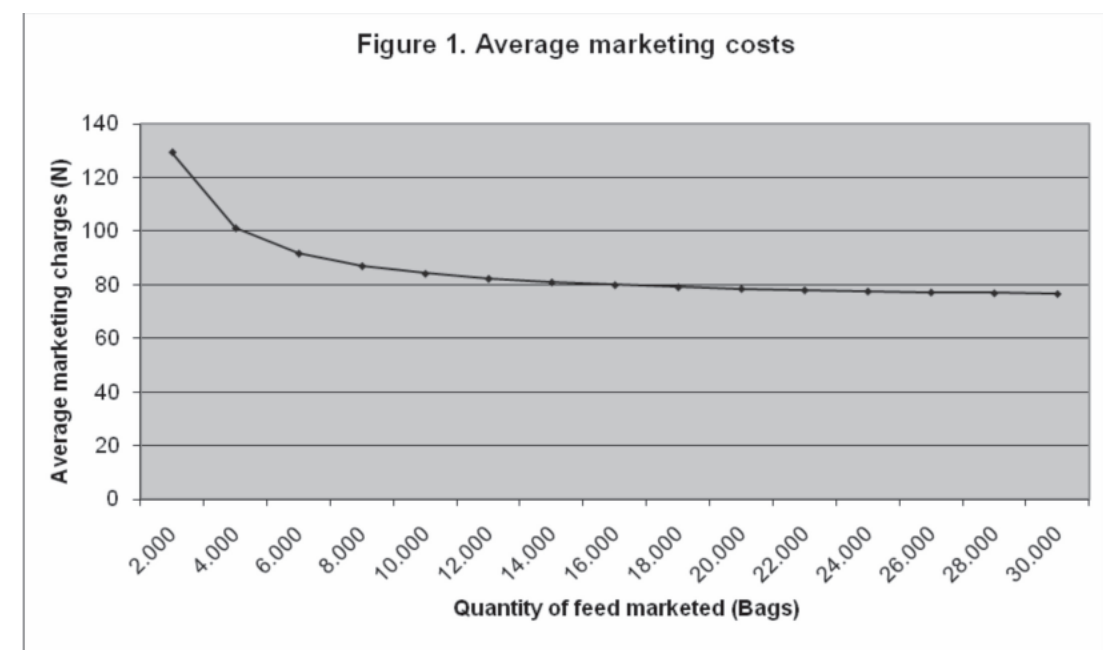


3.4. Relationship between Marketing Margin (MM) and Marketing Costs $(M C)$

The estimated equation obtained for MM as a function of $\mathrm{MC}$ are presented in equations (8) and (9).

$$
\mathrm{MM}=-248.825+1.390 \mathrm{MC}
$$

$\mathrm{F}=479.508$

$\underline{\mathrm{R}^{2}}=0.927$

$\mathrm{R}^{2}=0.925$

MS residual $=12648.425$

$$
\begin{aligned}
& \mathrm{MM}=-205.764+1.030 \mathrm{MC}+6.801 \mathrm{E}-04 \mathrm{MC}^{2}-2.96 \mathrm{E}-07 \mathrm{MC}^{3} \\
& \begin{array}{lll}
(1.077) \quad(0.002) & (0.000)
\end{array}
\end{aligned}
$$

$\mathrm{F}=153.415$

$\mathrm{R}^{2}=0.927$

$\mathrm{R}^{2}=0.921$

MS Residual $=13190.375$

Considering the adjusted $\mathrm{R}^{2}$ and the mean square residual, equation (8) was chosen as the lead equation. The equation indicates that $\mathrm{MC}$ is a significant explanatory variable of MM at 5 percent level in that it explains $93 \%$ of the total variability in MM. The regression coefficient of 1.390 suggests that a rise of $\mathrm{N} 1.00$ in $\mathrm{MC}$ will result in about $\mathrm{N} 1.40$ increase in MM. 


\subsection{Index of Pricing Efficiency}

The output of paired sample t-test used in comparing marketing margin with marketing costs is presented in Table 3.

Table 3 - Comparison of marketing margin and marketing costs

\begin{tabular}{|l|c|c|c|c|c|}
\hline & Mean & $\begin{array}{c}\text { Standard } \\
\text { Deviation }\end{array}$ & $\begin{array}{c}\text { Standard } \\
\text { Error Mean }\end{array}$ & t Computed & $\begin{array}{c}\text { t Tabulated } \\
0.05(39)\end{array}$ \\
\hline MC (N000) & 420.38 & 283.79 & 44.87 & & \\
\hline MM (AD00) & 755.60 & 687.22 & 48.87 & & \\
\hline $\begin{array}{l}\text { MM minus M } \\
\text { C (A000) }\end{array}$ & 335.23 & 409.72 & 64.78 & 5.175 & 2.021 \\
\hline
\end{tabular}

Source: Authors' computation.

T computed is higher than $t$ tabulated. The null hypothesis, which states that $\mathrm{MM}$ is equal to $\mathrm{MC}$ is hence rejected. This suggests that there is a significant difference between the MM and MC, which implies that there is no pricing efficiency in the market.

\subsection{Relationship between Marketing Margin (MM) and Quantity} Marketed (Q)

The estimated equation for the relationship between MM and Q is presented in equation (10). The regression was run stepwise and only $\mathrm{Q}$ entered the regression. The square and the cube of the quantity marketed were excluded.

$$
\begin{array}{r}
\mathrm{MM}=-112.293+0.107 \mathrm{Q} \\
(0.008)
\end{array}
$$

$\mathrm{F}=2989.861$

$\mathrm{R}^{2}=0.987$

$\mathrm{R}^{2}=0.987$

MS Residual $=2161.804$ 
The equation suggests that quantity marketed is a significant explanatory variable of marketing margin. The coefficient of quantity marketed is significant at $5 \%$ level while the quantity marketed explained about $99 \%$ of the variability in the marketing margin. This is an indication that there is no pricing efficiency in the market and it corroborates the results from the index of pricing efficiency.

\subsection{Performance by profit}

The computed profitability ratio is presented in Table 4 . The profitability ratio of 0.06 shows that for every $\mathrm{N} 100$ invested in the business, the feed marketing firm gained $\mathrm{N6.00}$. This confirms that feed marketing is profitable. The financial efficiency ratio is 1.06 , which indicates that the firms are financially efficient.

The analysis of profit per bag of feed shows that the least profitable firm in the industry made a negative unit profit of 13 kobo per bag of feed marketed while the most profitable firm made a positive unit profit of 10 kobo per bag of feed. The mean, median and mode unit profit were 5 kobo, 6 kobo and 3 kobo; respectively.

Table 4 - Cost and returns of feed marketing firms

\begin{tabular}{|l|r|}
\hline Total Cost ( $)$ & $238,459,460$ \\
\hline Total revenue (N) & $251,870,000$ \\
\hline Profit (N) & $13,410,540$ \\
\hline Profitability ratio (Profit/TC) & 0.06 \\
\hline Efficiency ratio (TR/TC) & 1.06 \\
\hline
\end{tabular}

Source: Authors' computation. 
The unit profit of each firm plotted against the quantity of feed marketed is presented in Figure 2. The figure shows that the unit profit was increasing as the quantity marketed increased. This finding corroborates the earlier findings that the advantage of economies of size has not been captured by the firms and that all firms are marketing at less than profit maximizing levels of output.

Figure 2. Performance by Profit

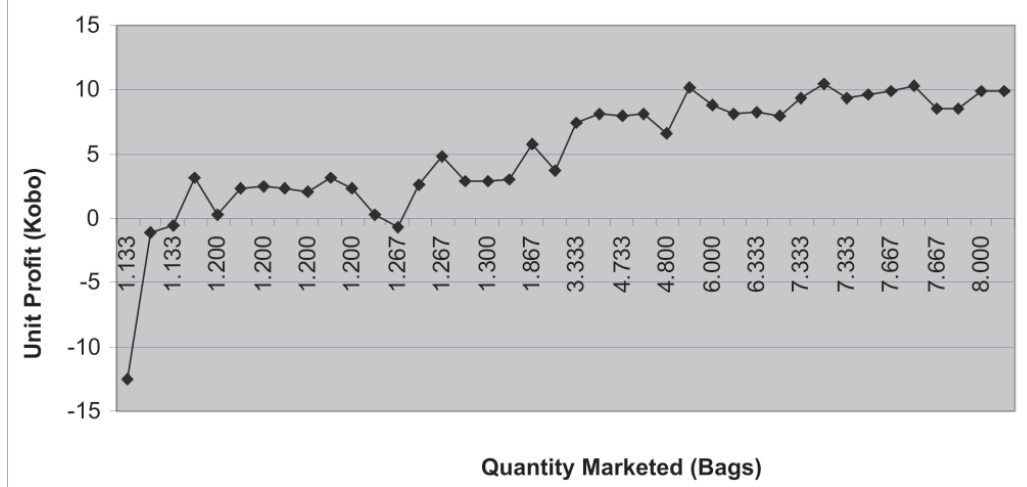

3.8. Performance by Efficiency

A transformation of the unit marketing costs into relative efficiency was undertaken. The minimum relative efficiency was $25 \%$. The mean was $65 \%$ while the median was $64 \%$. The mode was $51 \%$. The relative efficiency curve is presented in Figure 3 . This figure shows that relative efficiency seems to increase with volume marketed. This also suggests that firms in the industry should strive to increase the quantity of feed marketed. 


\section{Figure 3. Relative Efficiency Curve}

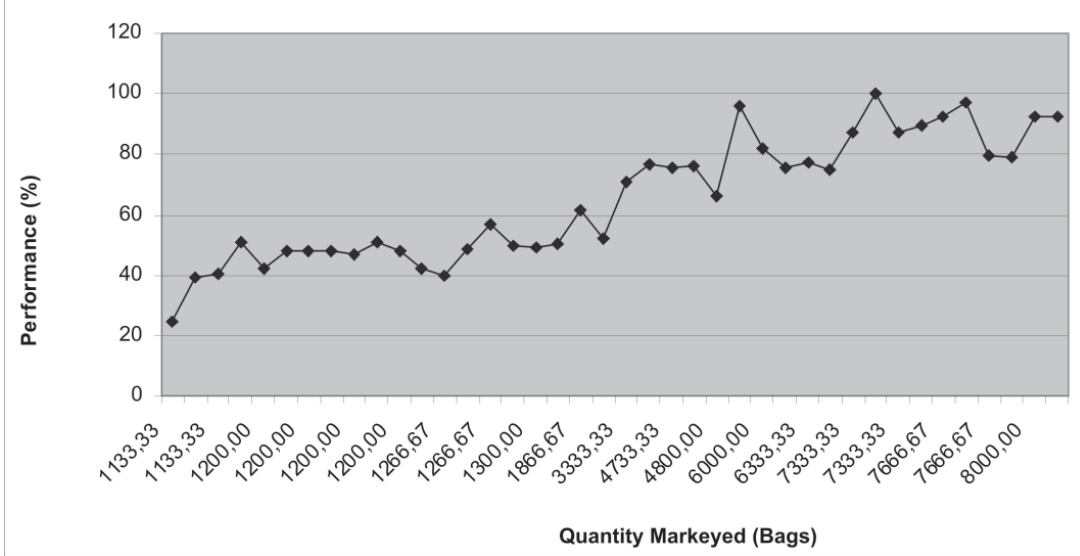

\section{Summary and Conclusion}

The poultry feed marketing firms studied which handled about N251,870,000 of feed per annum, had an annual ICC of $\mathrm{A} 4,587,762$ and an average ICC of $\$ 114,694$ per firm. The absolute ICC expressed as a percentage of the average inventory value was a maximum of $154.50 \%$ and minimum of $6.52 \%$. The mean was $64.92 \%$ and the median was

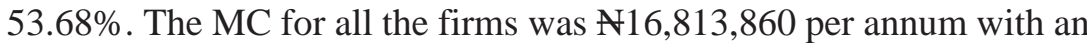
average MC of $\mathrm{N} 420,347$. The MC expressed as a percentage of the initial cost of feed marketed by respective firms ranged from $5.08 \%$ to $20.37 \%$. The mean was $8.55 \%$ while the median was $7.86 \%$. The major contributors to ICC were costs of storage space, handling and security while storage space, transportation and capital costs were major contributors to MC. The policy implication of these findings is that the poultry feed marketing firms should make efforts to minimize transportation cost and utilize storage space optimally. 
There is a need for the firms in the industry to increase the quantity of feed they are marketing to about 10,000 bags per annum as indicated by AMC curve which declined significantly between 2000 bags to 10,000 bags per annum and unit profit which increased over the same range.

Both MM and MC were found to be significantly different from each other which implied that there was no pricing efficiency in the market. This is corroborated by the fact that quantity marketed was a significant explanatory variable of MM.

The minimum relative efficiency in the industry was $25 \%$. The mean was $65 \%$ while the median was $64 \%$. The mode was $51 \%$. Relative efficiency increased with the quantity marketed. The implication of these findings is that firms in the industry should strive to increase the quantity of feed marketed.

The major contribution of this study is that it provides information on the components of marketing costs and size economies in the poultry feed industry in Ondo State, Nigeria. The major limitation of this study is that it is focused at the feed market in only Ondo State which is one of the 36 states in Nigeria and by so doing missed the opportunity of a comparative analysis of feed markets across some states of Nigeria. 


\section{References}

ADENE ,D.F.; OGUNTADE A. E. (2006). The structure and importance of the commercial and village based poultry industry in Nigeria. FAO (Rome), 109 pp (Technical Report) http://www.fao.org/ docs/eims/upload//214281/poultrysector_nga_en.pdf

ARENE, C.J. Introduction to Agricultural Marketing Analysis for developing Economies. Fulladu Publishing Press Nsukka, Nigeria, 1998, p18.

BABATUNDE, R.O.; OYATOYE, E. "Food Security and Marketing Problems in Nigeria: The Case of Maize Marketing in Kwara State". The Global Food and Product Chain - Dynamics, Innovations, Conflicts, Strategies, Proceedings of Tropentag 2005, Tielkes, E., Hulsebusch, C., Hauser, I., Deininger, A. and Becker, K. (eds.), 2005, 475-484. Published by Centre for Agriculture in the Tropics and Subtropics, University of Hohenheim, Stuttgart, Germany. Available online at www.tropentag.de

CRAWFORD I. M. Agricultural and food marketing management. FAO (Rome), 1997, 290 pp http://www.fao.org/ DOCREP/004/W3240E/ W3240E12.htm\#ch12.4

FOLAYAN, J. A; OGUNTADE A. E.; OGUNDARI K. Analysis of profitability and operational efficiencies of cocoa marketing: empirical evidence from Nigeria. J. Soc. Sci., 2007, 15(2): 197-199

HAU A. M.; OPPEN M. The efficiency of the vegetable market in Northern Thailand Conference on International Agricultural Research for Development, Deutscher Tropentag Berlin, October 5-7, 2004. www.avrdc.org/publications/socio/veg_industry/Thailand.pdf 
HERRUZO, A.C.; MOROTE, F. Regional advantages and economies of size in Spanish rice farming Cahiers Options Méditerranéennes, 1996, vol. $15, \mathrm{n}^{\circ} 2$.

KÄHKÖNEN, S.; LEATHERS S. Transaction costs analysis of maize and cotton marketing in Zambia and Tanzania. Technical Paper No. 105, IRIS Center, University of Maryland, 1999. 104 pp.

KER, A.; HOWARD, W.H. Economies of Size in the Ontario Swine Industry. Working Paper Series wp93/08. Department of Agricultural Economics, University of Guelph. Ontario, 1993.

KOHLS R.L.; UHL, J.N. Marketing of Agricultural Products, 6th edition. New York McMillan Press, 1985.

MAFIMISEBI, T.E. Yield of investment in large-scale production and distribution of eggs in Ibadan metropolis. Tropical Animal Production Investigations, 2002, Vol 5(2):91-101

MAFIMISEBI T.E.; OKUMADEWA. F.Y.; WRIGHT A.D. Marketing margin differentials at three levels of the egg distributive chains in Ibadan metropolis. Tropical Journal of Animal Science, 2002, Vol 5(1):53-63.

MAUYO L. W.; OKALEBO J. R.; KIRKBY R. A.; BURUCHARA R.; UGEN M.; MENGIST C.T.; ANJICHI V.E.; MUSEBE R.O.Technical efficiency and regional market integration of cross-border bean marketing in western Kenya and eastern Uganda. African Journal of Business Management, 2007, pp. 077-084, http:// www.academicjournals.org/ajbm.

MITCHEL, K..; GEMPESAW II, C.M.; BIERY, C.S. Current status and competitiveness of US poultry exports. Journal of International Food and Agribusiness Marketing, Vol. 10 Nr. 4, 1999. 
OLADAPO, M.O.; MOMOH, S.; YUSUF, S.; AWOYINKA, Y. Marketing margin and spatial pricing efficiency of pineapple in Nigeria. Asian J. Market., 2007, 1: 14-22.

OLUKOSI, J.O.; ISITOR, S.V. Introduction to Agricultural Market and Price: Principles and Applications. Agitab Publishers, Zaria, 1990. Pp 34.

STEFANOU, S. E.; MADDEN, J. P. Economies of size revisited. Journal of Agricultural Economics, 1988, 39: 125-132.

TAIWO, A. The roles of the feed mill industry in livestock production. Ibadan University Press, 1989.

UNANG, I. Profitability and efficiency of the broiler industry in Tasikmalaya. Faculty of Agriculture University of Siliwangi Tasikmalaya Indonesia, 2003. http://www.stanford.edu/group/FRI/indonesia/research/ broilers.pdf

UGWUMBA, C. O. A. Analysis of fresh maize marketing in Anambra State, Nigeria. Journal of Research in National Development, 2009, Vol. 7:2 http://www.transcampus.org/ JORINDV7Dec2009/JournalsV7NO2Dec2009.html

WARRACK, A. A. A conceptual framework for analysis of market efficiency. Canadian Journal of Agricultural Economics/Revue canadienne d'agroeconomie, 1972, 20: 9-22. doi: 10.1111/j.17447976.1972.tb01006.x

WATSON, D.S.; HOLMAN, M.A. Price Theory and Its Uses. Houghton Mifflin Company, Boston, 1977. 445 pp 
Resumo: O setor comercial de aves da Nigéria é dependente de rações comerciais. Avaliação das eficiências operacional e de preços na comercialização de rações para aves é essencial para melhorar a eficiência na indústria de alimentos e reduzir os preços dos produtos avícolas. Uma técnica de amostragem de múltiplos estágios foi utilizada para selecionar as empresas estudadas. Os métodos usados para analisar os dados coletados incluíram índices de eficiência operacional e de preços, e análise de regressão. As empresas estudadas movimentaram cerca de $\mathbf{N} 251,870.000$ em rações por ano, tiveram um custo anual de reposição de estoques (ICC) de $\mathbf{N}$ 4, 587.762 e um custo médio de reposição de estoques de $\mathbf{N} 114,694$ por firma. Os custos de comercialização (MC) para todas as firmas foram de $\mathbf{1 6}, 813.860$ por ano, enquanto o custo médio de comercialização foi de 420,347. Os principais fatores que contribuíram para o ICC foram o armazenamento e manejo, enquanto os custos de transporte, armazenamento e custos de capital foram os principais fatores que contribuíram para o MC. Os esforços para minimizar os custos devem, portanto, ser focados na redução dos custos de transporte e utilização ótima do espaço de armazenamento. Os custos médios de comercialização (AMC) diminuíram com o aumento na quantidade comercializada $(\mathrm{QM})$, enquanto o lucro unitário aumentou com a QM. Assim, as firmas precisam aumentar a QM. As margens de comercialização (MM) e MC foram significativamente diferentes entre si. Além disso, a QM foi uma variável explanatória significativa da MM, o que implica que não houve eficiência de preços no mercado. A eficiência relativa aumentou com a QM, sugerindo que as empresas devem se esforçar para aumentar a quantidade de rações comercializadas. A principal contribuição deste estudo é que ele fornece informações sobre os componentes dos custos de comercialização e economias de escala na indústria de ração para aves no Estado de Ondo, na Nigéria.

Palavras-chave: Rações para aves, eficiência operacional, eficiência de preços, custos de comercialização, Nigéria. 
REVISTA DE ECONOMIA E AGRONEGÓCIO, VOL.8, $N^{o} 2$ 